KOKSAL N; INCESU M; TEKE A. 2015. Supplemental LED lighting increases pansy growth. Horticultura Brasileira 33: 428-433. DOI - http://dx.doi. org/10.1590/S0102-053620150000400004

\title{
Supplemental LED lighting increases pansy growth
}

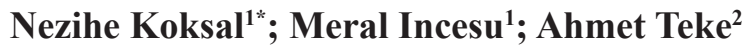

${ }^{1}$ Çukurova University, Faculty of Agriculture, Dep. Horticulture, Adana, Turkey; *corresponding author; nkoksal@cu.edu.tr; mincesu@ cu.edu.tr; ${ }^{2}$ Cukurova University, Faculty of Engineering and Architecture, Dep. Electrical and Electronic Engineering, Adana, Turkey; ahmetteke@cu.edu.tr

\begin{abstract}
Pansy (Viola cornuta) is a facultative long-day plant that flowers from October until March in Turkey. During the winter months, low light levels can limit plant growth and development. Light emitting diodes (LEDs) can provide supplemental lighting in greenhouses which produce same light intensity with less energy than conventional incandescent lighting. Light emitting diode technologies have enabled affordable and efficient light systems to be installed in greenhouses and plastic tunnels in the field. In this experiment we evaluated the effects of supplemental red-orange LED lightening on the growth and development of pansy cv. Blue Blotch grown in plastic tunnels. The energy, which LEDs are to consume, was provided through a solar panel system with the aim of drawing attention to the cleanliness of solar energy source. Five hours of supplement LED lighting was applied after dusk starting from November to February. Pansy growth and development parameters were compared with non-light supplied control plants. Supplemental LED lighting significantly increased plant biomass weight, flower number and leaves number at the rate of $52 \%, 72 \%$, and $47 \%$, respectively. Moreover, LED lighting increased plant growth rate ( 0.109 and $0.306 \mathrm{~g}$ of fresh weight), compared with the no light control. LED lighting, however, had no effect on length of stems, number of branches and the diameter of flowers. Thus, this study indicated that pansies are light limited during the winter months and supplemental LED lighting can significantly increase pansy growth and development.
\end{abstract}

Keywords: Viola cornuta, solar energy, ornamental plants.

\section{RESUMO}

Iluminação suplementar por lâmpadas LED aumenta o crescimento da Viola cornuta

A Viola cornuta é uma planta facultativa de dias longos que floresce de outubro até março, na Turquia. Durante os meses de inverno, os baixos níveis de luz podem limitar o crescimento e desenvolvimento da planta. Diodos emissores de luz (LEDs) podem fornecer iluminação suplementar em estufas produzindo a mesma intensidade de luz que uma lâmpada incandescente convencional, com menor consumo de energia. As tecnologias de emissão de luz através de diodos permitem sistemas acessíveis e eficientes que podem ser instalados em estufas e túneis de plástico no campo. Neste experimento avaliou-se os efeitos da suplementação por LED vermelho-alaranjado no crescimento e desenvolvimento de Viola cornuta, cv. Blue Blotch, cultivada em túneis plásticos. A energia necessária para o funcionamento dos LEDs foi fornecida através de um sistema de painéis solares com o objetivo de chamar a atenção para a fonte de energia solar não poluente. Cinco horas de iluminação suplementar por LED foram aplicadas após o entardecer, de novembro a fevereiro. Parâmetros de crescimento e desenvolvimento do amor perfeito foram comparados com o não fornecimento de luz às plantas testemunha. Iluminação suplementar por LED aumentou significativamente o peso da biomassa da planta, número de flores e número de folhas à taxa de 52,72 e $47 \%$, respectivamente. Além disso, a iluminação LED aumento a taxa de crescimento das plantas (0,109 e $0,306 \mathrm{~g}$ de peso fresco), em comparação com o controle sem luz. Iluminação por LED no entanto, não teve efeito sobre o comprimento do caule, número de ramos e o diâmetro das flores. Assim, este estudo indicou que o amor perfeito sofre limitação no seu desenvolvimento pela menor iluminação durante os meses de inverno e, iluminação suplementar por LED pode aumentar significativamente o crescimento e o seu desenvolvimento.

Palavras-chave: Viola cornuta, energia solar, plantas ornamentais.

(Recebido para publicação em 26 de agosto de 2014; aceito em 28 de maio de 2015) (Received on August 26, 2014; accepted on May 28, 2015)

$\mathrm{D}$ uring the growth of plants, the required sources of the light are provided by either the sun or artificial lights (Kim et al., 2004). Not only is light a simple energy source for plants during the photosynthesis, but it is also an important factor having the control over the process, thus leading different developmental processes (Lee et al., 2007; Li et al., 2012; Jung et al., 2013). In some cases, under low light conditions during the winter months, the use of artificial lighting is necessary to promote plant growth
(Chia \& Kubota, 2010). Supplemental lighting is remarkably important among the automation systems used in greenhouses.

Bedding plants production is increasing in Turkey. Pansy (Viola spp.) is a bedding plant which has the 
ability to remain in flower in moderate climates from the end of October until May in the Northern Hemisphere and Turkey also. As in the case of many other plants, light quantity and quality is critical for successful pansy production (Runkle \& Heins, 2004). Plant weight, plant height, internode length, branch number and leaf size are influenced by light quality and quantity (Fan et al., 2013). Red-orange light (600-700 nm wavelength) can stimulate hypocotyl and stem elongation (Chia \& Kubota, 2010; Yang et al., 2012), increase leaf area index, and activate phytochrome (Johkan et al., 2012). Blue light can also increase hypocotyl, stem and internode elongation and plant growth (Johkan et al., 2010, 2012).

Recent innovations in inexpensive lighting systems have increased interest in their use in greenhouse cultivation. Especially under low light conditions during the winter months, artificial lighting can increase plant growth (Chia \& Kubota, 2010). LED grow lights have become increasingly common in greenhouse production because they can increase plant growth during the periods when there is insufficient amount of sun light (Johansen et al., 2011; Yang et al., 2012; Sirtautas et al., 2014).

LED lighting has been recently installed in greenhouses in Turkey because they are efficient and environmentally friendly over other existing artificial illumination sources. LEDs are used for plant growing, with better results in energy consumption compared to fluorescent lamps (Massa et al., 2008; Olvera-Gonzalez et al., 2013). LED lamps provide energy savings up to $75 \%$ and $30 \%$ compared with incandescent and fluorescent lamps, respectively. In addition, the life of a standard lamp is about 1,000 hours, whereas the average life of LED lamps is 20,000-50,000 hours (Köksal et al., 2013). LEDs have many additional advantages, such as small size, specific wavelength, low thermal output, adjustable light intensity and quality, as well as high photoelectric conversion efficiency (Yeh \& Chung, 2009). Furthermore, LED lamps provide illumination without damaging the plants due to not emit ultraviolet or infra-red radiation and not contain mercury or lead (Morrow, 2008; Yeh \& Chung, 2009). Moreover, the LED's energy source can be provided by solar panels which allow these systems to be placed in tunnels out in the field away from energy grid.

There are few studies, however, investigating the effects of LED grow lights on ornamental plant growth and development. The aim of the study was to evaluate the use of supplemental red-orange LED lighting for greenhouse pansy (Viola cornuta) production in the Cukurova region of Turkey.

\section{MATERIAL AND METHODS}

Blue Blotch pansy (Viola cornuta) seeds were germinated in perlite and peat $(1: 1)$ in plastic germination trays in greenhouse in Cukurova University, Faculty of Agriculture, Department of Horticulture in Adana, Turkey at the beginning of September, 2010. The temperature and relative humidity ranged between $26-28^{\circ} \mathrm{C}$ and $65-75 \%$, respectively, in greenhouse. Uniform sized seedlings (35-day old) which are in soil media in pots $(1.5 \mathrm{~L})$ were selected and transplanted to tunnels. Some of these plants were exposed to supplemental LED lighting, grown under specifically designed plastic tunnels by the Cukurova University, Faculty of Engineering and Architecture, Department of Electrical and Electronic Engineering in Adana. The tunnels were divided into two equal parts by a black plastic barrier, each of which consists of $1 \mathrm{~m}^{2}$ area per each experimental plot. The dimension of each plot is $1 \times 1 \times 1 \mathrm{~m}$. The experiment was carried out from November to February 2010 for a period of four months. Five uniform seedlings were planted in each plot. All conditions in the tunnels were similar except half of the plants received supplemental LED for five hours after dusk. Photocells activated LED lamps.

At the beginning of the study some characteristics of the plants were determined to evaluate changes at the end of the research, such as root weight (5.75 g); shoot weight (5.00 g); plant weight (10.75 g); root/shoot ratio (1.15) and leaf number (33).

At the end of four months, plants were harvested and plant fresh weights were determined using a sensitive balance. At the end of the 120 days, plant growth rate based on the changes of plant weights was also evaluated. The number of branches, leaves and flowers were counted. Plant branches, stem, and pedicels were measured using a ruler. Leaf chlorophyll concentration was estimated using a portable SPAD502 meter (Minolta, Osaka, Japan). Photosystem II (PSII) was measured with a portable fluorimeter (Photon System Instruments Ltd) in the fully developed leaf of each plant. Measurements were taken in the two youngest fully expanded leaves of each replicate.

The block diagram of installed experimental prototype is shown in Figure 1. LED grow lamp features included: Brand-Helmet, Model5H4URCW, Lens size-5, Light color: red-orange, Light wavelength: $623 \mathrm{~nm}$, Viewing angle: $100^{\circ}$, Light intensity: 350-800 mcd, Forward voltage (V), Typical-2, Max-2.4, Forward current: 20 mA, 9W. 180-W (2*90-W, 12V) PV system is selected for LED grow lamps (9-W, 24V- $40 \mu \mathrm{mol} / \mathrm{m}^{2} / \mathrm{s}$ Photosynthetic Photon Flux Density (PPFD) considering the future large scale studies. PV system can generate nearly 720-Wh energy during the day. The total solar energy potential of Adana is nearly $1,390 \mathrm{kWh} /$ $\mathrm{m}^{2} /$ year, and total sun time is 2,956 hours/year. The total solar radiation is $350,8634 \mathrm{cal} / \mathrm{cm}^{2}$. The cloudy days in Adana during the tests are considered as two days which means that $1440-\mathrm{Wh}$ stored energy is required. The battery group is selected as $2 *(100 \mathrm{Ah} / 12 \mathrm{~V})$ considering the future studies. The solar charge regulator is selected as $24 \mathrm{~V} / 15$ A. The inverter is selected as 600W (24 $\left.\mathrm{V}_{\mathrm{DC}} / 220 \mathrm{~V}_{\mathrm{AC}}\right)$. The other apparatus are photocell, timer, watt transducer, data logger, PC, experimental test setup and a lux meter.

Significant differences between plants grown under LED lighting system and control plants were determined via t-test $(\mathrm{p}<0.01$ and $\mathrm{p}<0.05)$. Statistical analyses were performed by using SAS v9 software. The treatments were 
replicated three times and with five plants comprising the experimental unit.

\section{RESULTS AND DISCUSSIONS}

Supplemental red-orange LED lighting $\left(40 \mu \mathrm{mol} / \mathrm{m}^{2} / \mathrm{s}\right.$ PPFD) significantly increased many plant growth parameters of pansy (Table 1). Root and shoot fresh weight, root/shoot ratio, length of branches, leaf number, flower number, length of pedicel were affected by supplemental LED lighting. Compared to control, supplemental LED lighting increased fresh weight of roots and shoots at the rate of $161 \%$ and $52 \%$, respectively. Root/shoot ratio of plants grown on supplemental LED light were 1.9 times greater when compared to those ones grown without supplemental light. Total plant weight of LED lighted plants was two times more than control plants. Branch length increased by $42 \%$ with supplemental LED lighting. The number of leaves and flowers increased by supplemental LED light compared to the control, at the rate of $47 \%$ and $72 \%$, respectively. Pedicel length increased by $22 \%$ with supplemental LED light compare to control. Supplemental LED lighting however, had no effect on main stem length, number of branches and flower size (Table 1). A picture of pansy plants grown with and without additional lighting is shown in Figure 2. As can be seen in the picture, supplemental LED lighting increased market value of the plants.

According to Figure 3, PSII changed significantly between control and LED light treatments. PSII increased at the rate of $3 \%$ with supplemental LED lighting compare to control. Supplemental LED lighting, however, had no significantly effect on SPAD.

Plants grown with supplemental LED lights were significantly larger and thus more economically valuable to the grower. This results indicated that the plants were light limited during their growth period. Root weight of pansy increased with and without supplemental LED lighting by 1.8 and 4.9 times, respectively, during growing period. On the other hand, increasing of

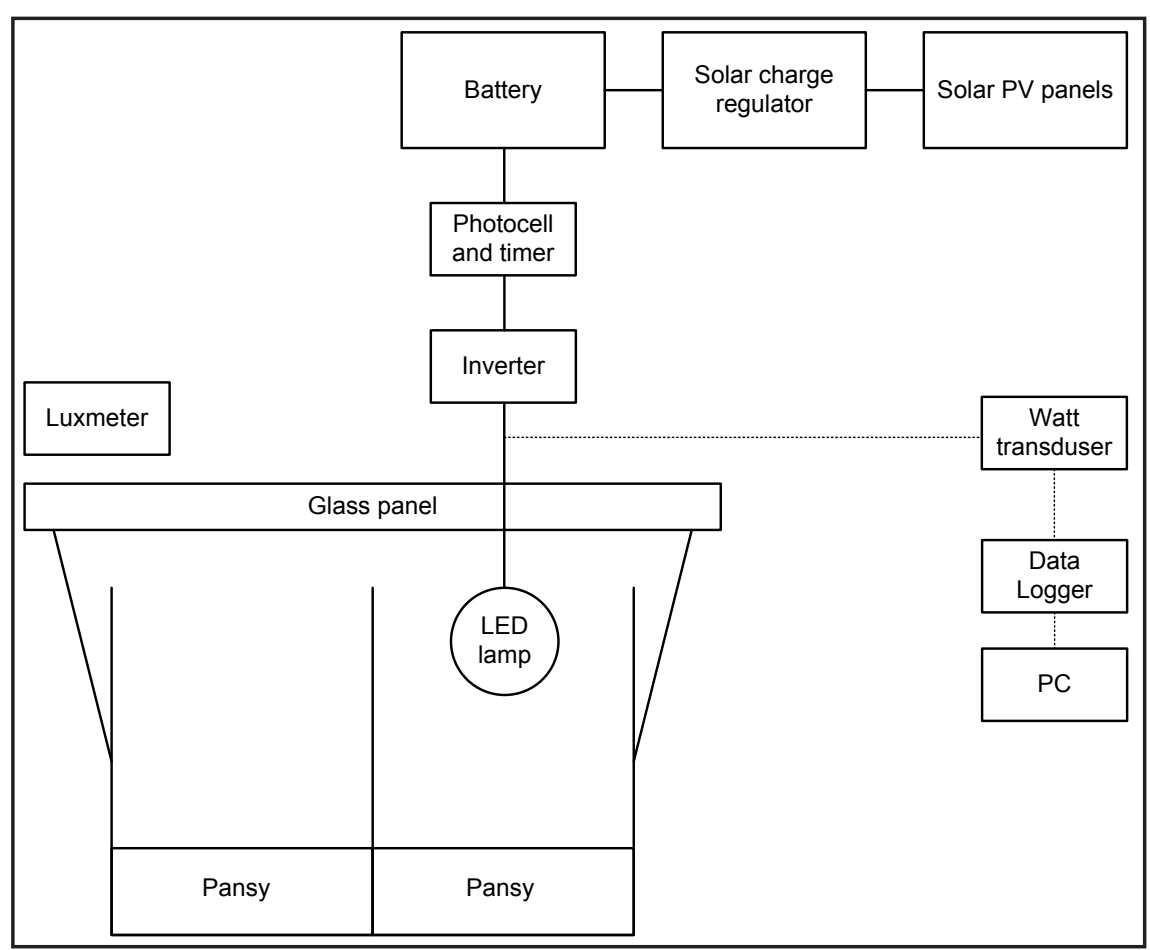

Figure 1. The prototype of LED growth system (protótipo do sistema de crescimento LED). Turkey, Cukurova University, 2010.

shoot weight was by 2.7 and 4.1 fold for control and supplemental LED lighting, respectively. According to the beginning of the growth period, root to shoot ratio increased by $15 \%$ with supplemental led lighting whereas root to shoot ratio decreased by $33 \%$ for control plants. Leaf number increased by control and LED treatments at the rate of 3.7 and 5.4 fold, respectively. After pansies were transplanted into the plastic tunnels, total plant growth rates were 0.109 and $0.306 \mathrm{~g} /$ day for the control and LED treatments, respectively. Thus, plant weight of pansy was increased by 2.8 fold with five hours of supplemental LED lighting compared to the control during their growth period.

There are significant effects of the different wavelengths of light source on the physiology and growth of plants. Red-orange light (600-700 nm wavelength) is effective on the increase in leaf area and biomass (Johkan et al., 2012); blue light has an effect on the hypocotyl elongation and biomass (Johkan et al., 2010, 2012) and green light is effective on the leaf development and stem elongation (Folta, 2004; Kim et al., 2004). In recent years, due to its advantages, the use of LED lamps in

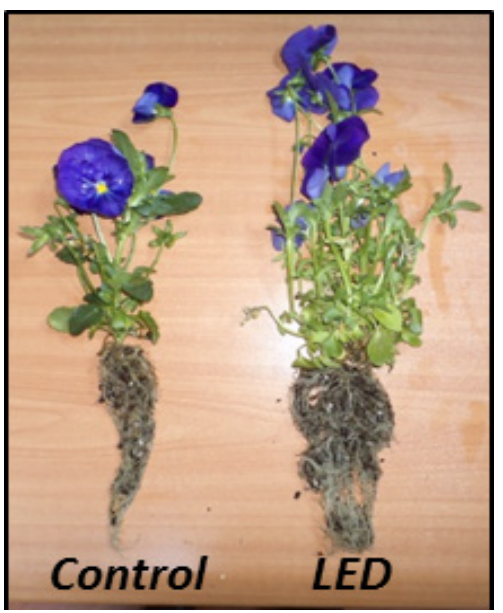

Figure 2. Blue Blotch pansy (Viola cornuta) plants grown under low plastic tunnels without additional lighting (control group) and with five hours of supplemental LED lighting \{ plantas de Viola cornuta cultivadas sob tunel plástico sem (testemunha) e com iluminação adicional por iluminação LED \} . Turkey, Cukurova University, 2010.

the cultivation of greenhouse plants is a subject of interest. Depending on its own features, each plant species reacts differently to the light source and light wavelength.

Li et al. (2012) reported that root and shoot fresh weight of Chinese cabbage 


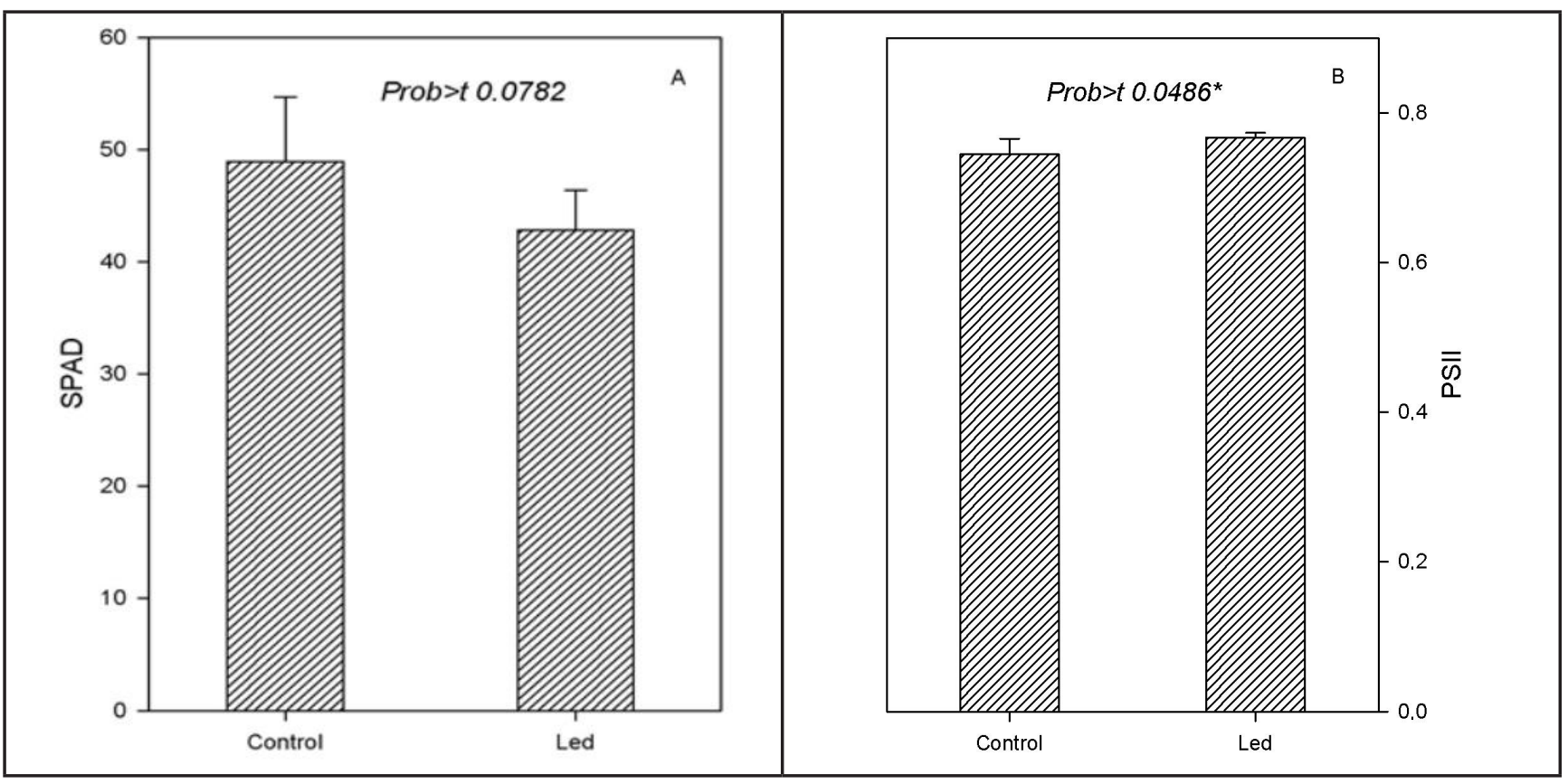

Figure 3. SPAD and Photosystem II (PSII) of Blue Blotch pansy (Viola cornuta) plants grown under low plastic tunnels without (control group) or with five hours of supplemental LED lighting. X axis indicates plants grown without supplemental light and with supplemental LED light at the end of the experiment: $\mathrm{A}=\mathrm{SPAD} ; \mathrm{B}=\mathrm{PSII}$ \{indices SPAD e PSII em plantas de Viola cornuta cultivadas sob tunel plástico sem (plantas controle) ou com suplementação de 5 horas de iluminação LED. Eixo X indica plantas cultivadas sem ou com iluminação suplementar por lampadas LED. A=SPAD; B= PSII\}. Turkey, Cukurova University, 2010.

Table 1. Pansy plants growth (Viola cornuta) and development characteristics when cultivated under low plastic tunnels without (control group) or with five hours of supplemental LED lighting (crescimento e caracteristicas de desenvolvimento de plantas de Viola cornuta cultivadas sob tunel plástico sem (testemunha) ou com suplementação LED de iluminação\}. Turkey, Cukurova University, 2010.

\begin{tabular}{lrrc}
\hline Plant growth parameters & \multicolumn{1}{c}{ Control } & \multicolumn{1}{c}{ LED } & t test (prob>t) \\
\hline Root weight $(\mathrm{g})$ & $10.33 \pm 3.95$ & $26.99 \pm 3.90$ & $0.0010^{* *}$ \\
Shoot weight $(\mathrm{g})$ & $13.53 \pm 2.21$ & $20.51 \pm 3.24$ & $0.0119^{*}$ \\
Root/shoot ratio & $0.69 \pm 0.17$ & $1.32 \pm 0.14$ & $0.0010^{* *}$ \\
Stem length (cm) & $11.38 \pm 1.29$ & $12.00 \pm 1.58$ & $0.5132^{\text {(NS) }}$ \\
Number of branches/plant & $5.50 \pm 1.29$ & $7.68 \pm 1.69$ & $0.0877^{\text {(NS) }}$ \\
Length of branches (cm) & $6.87 \pm 0.74$ & $9.75 \pm 1.62$ & $0.0068^{* *}$ \\
Number of leaves/plant & $121.75 \pm 15.44$ & $179.00 \pm 22.09$ & $0.0054^{* *}$ \\
Number of flowers/plant & $8.00 \pm 1.00$ & $13.75 \pm 4.15$ & $0.0167^{*}$ \\
Length of pedicel (cm) & $8.55 \pm 0.51$ & $10.41 \pm 0.78$ & $0.0021^{* *}$ \\
Flower diameter $(\mathrm{cm})$ & $5.28 \pm 0.33$ & $5.38 \pm 0.23$ & $0.5798^{\text {(NS) }}$ \\
\hline
\end{tabular}

$\mathrm{NS}=$ Not significant (não significativo); ${ }^{* *},{ }^{*}$ Significant at 1 and 5\%, respectively (significativo a 1 e $5 \%$, respectivamente).

were increased with low red light $(80$ $\mu \mathrm{mol} / \mathrm{m}^{2} / \mathrm{s}$ PPFD) treatment. For tomato plants (Brazaitytè et al., 2010; Köksal et al., 2013) and for cucumber seedlings (Su et al., 2012), positive effects were observed of LED lighting on plant weight. Similarly, red-orange light had promoter effects on root and shoot fresh weight of pansy. Thus, in the present study, root to shoot ratio increased with red-orange LED lighting. Similarly,
Samuolienė et al. (2010) demonstrated that strawberry plants submitted to red light had more roots than shoots. They also indicated that combination of red plus blue light resulted in greater root and lower leaf formation.

In this study, LED lighting had no effect on the length of stem (Table 1); however, a promoter effect was detected on the length of branches. Similarly, in many previous studies was reported that red-LED light is ineffective on plant height. The effect of red light on plant height seems inconsistent $(\mathrm{Wu}$ et al., 2007). Red light inhibited shoot elongation in marigold and salvia (Heo et al., 2002). Li \& Kubota (2009) demonstrated that supplemental redlight had no effect or minimal effect on stem length of baby lettuce compared to white light. Brazaityte et al. (2010) also related that orange light did not 
have a significant difference compared to the other colors of LED lights in terms of plant length. Moreover, Islam et al. (2012) mentioned various effects of EOD supplemental lighting treatments (at the end of day) on plant height of poinsettia. EOD treatments significantly reduced the height of Poinsettia cv. Advent-Red when High Pressure Sodium (HPS) was used as a supplemental lighting. But EOD-R treatment (red-LED at the end of day) had no effect on height. EOD-R had no significant effect on height of Poinsettia cv. Christmas Eve. On the other hand, Su et al. (2012) indicated that plant height of cucumber seedlings increased by supplemental red-LED light treatment.

Supplemental red-orange LED lighting for five hours had a positive effect on leaf and flower number of pansy plants. Similarly, in previous studies, the number of leaves on tomato plants was increased with four or five supplemental hours of red-LED lighting (Brazaitytè et al., 2010; Köksal et al., 2013). Supplemental red-LED light has a promoting effect on leaf number ( $\mathrm{Su}$ et al., 2012). Li et al. (2012) indicated that the number of flowers on Chinese cabbage was increased by red lighting. Samuolienè et al. (2010) found that the pedicel length of strawberries was increased with red-LED treatment compare to red+blue one.

Supplemental red-orange LED lighting had no promoter effect on SPAD value. Similarly, Shin et al. (2012) determined that SPAD values were lower in plants grown with redLED light compare to red+blue or blue LED light. Bach \& Krol (2001) indicated that red light $(647-770 \mathrm{~nm})$ reduced the amount of chlorophylls and carotenoids in embryogenic callus of Hyacinthus orientalis. Brazaityte et al. (2009) found smallest chlorophyll $a / b$ ratio in cucumber leaves grown under modules with supplemental green (520 $\mathrm{nm})$ and orange (622 nm) LEDs. Li et al. (2012) mentioned that inhibitory effects of red LED light on photosynthesis depended on the starch accumulation in chloroplasts. Li \& Kubota (2009) also indicated that supplemental red-light had no effect on chlorophyll content of baby lettuce compared to white light.
On the other hand, Yang et al. (2013) found that chrysanthemum plants grown with low red:far-red (R:FR) ratio (2.5) of LED had higher chlorophyll content than plants grown on higher $\mathrm{R}: F R$ ratio (6.5) of LED.

The chlorophyll fluorescence parameter (PSII) of the pansy grown with supplemental orange-red light was higher than on plants grown without supplemental light. It is thought that these results are derived from low LED light $\left(40 \mu \mathrm{mol} / \mathrm{m}^{2} / \mathrm{s}\right)$ which was used in the study. Similarly, Ilieva et al. (2010) demonstrated that the LED light (70\% red, $20 \%$ green and 10\% blue light) was effective on quantum yield of Photosystem II ( $\left.{ }_{\text {PSII }}\right)$; They indicated that both lettuce and radicchio plants grown at low light $\left(220 \mu \mathrm{mol} / \mathrm{m}^{2} / \mathrm{s}\right.$ PPFD) expressed higher photochemical activity of Photosystem II (PSII) than plants grown at high light $(400 \mu \mathrm{mol} /$ $\mathrm{m}^{2} / \mathrm{s}$ PPFD), evaluated by ${ }_{\text {PSII. }}$

LED lights are increasingly becoming widespread in terms of additional sources in plant cultivation. Advantages make LEDs perfect for supporting plant growth in controlled environment such as greenhouse cultivation, plant tissue culture room and growth chamber. Depending on its own features, each plant species reacts differently to the light source and light wavelength. The energy consumed by LEDs was provided through a solar panel system as an approach environmentally friendly.

The use of red-orange LED lights creates a significant difference in terms of plant weight, the length of branches, the number of leaves, the number of flowers and the length of pedicel of pansy plants. The results have shown the availability of red-orange LED lights during the process of the pansy cultivation. Furthermore, they also provide a basis for the studies based upon the additional lighting of LED technology, which will be performed with other bedding plants.

\section{ACKNOWLEDGEMENTS}

The authors are grateful to Dr. Richard Rosecrance for critical reading and English corrections of the manuscript. The authors also wish to thank and acknowledge the financial supported by Scientific Research Project Unit of Cukurova University (Project number: MMF2011BAP10).

\section{REFERENCES}

BACH A; KROL A. 2001. Effect of light quality on somatic embryogenesis in Hyacinthus orientalis Delfts Blue. Biological Bulletin of Poznan 38: 103-107.

BRAZAITYTE A; DUCHOVSKIS P; URBONAVIČIŪTĖ A; SAMUOLIENE் G; JANKAUSKIENÉ SAKALAUSKAITÉ J; ŠABAJEVIENĖ G; SIRTAUTAS R; NOVIČKOVAS A. 2010. The effect of lightemitting diodes lighting on the growth of tomato transplants. Zemdirbyste Agriculture 97: 89-98.

BRAZAITYTÉ A; DUCHOVSKIS P; URBONAVIČIŪTÉ A; SAMUOLIENE G; JANKAUSKIENĖ J; KASIULEVIČIŪTĖBONAKÉRE் A; BLIZNIKAS Z; NOVIČKOVASA; BREIVĖ K;ŽUKAUSKAS A. 2009. The effect of light-emitting diodes lighting on cucumber transplants and aftereffect on yield. Zemdirbyste-Agriculture, 96: 102-118.

CHIA PL; KUBOTA C. 2010. End-of-day far-red light quality and dose requirements for tomato rootstock hypocotyl elongation. HortScience 45: 1501-1506.

FAN XX; XU ZG; LIU XY; TANG CM; WANG LW; HAN XL. 2013. Effects of light intensity on the growth and leaf development of young tomato plants grown under a combination of red and blue light. Scientia Horticulturae 153: 50-55.

FOLTA KM. 2004. Green light stimulates early stem elongation, antagonizing light mediated growth inhibition. Plant Physiology 135: 1407-1416.

HEO J; LEE C; CHAKRABARTY D; PAEK KY. 2002. Growth responses of marigold and salvia bedding plants as affected by monochromic or mixture radiation provided by a light-emitting diode (LED). Plant Growth Regulation 38: 225-230

ILIEVA I; IVANOVA T; NAYDENOV Y; DANDOLOV I; STEFANOV D; 2010. Plant experiments with light-emitting diode modüle in Svet space greenhouse. Advances in Space Research 46: 840-845.

ISLAM MA; KUWAR G; CLARKE JL; BLYSTAD DR; GISLERØD HR; OLSEN JE., TORRE S. 2012. Artificial light from light emitting diodes (LEDs) with a high portion of blue light results in shorter poinsettias compared to high pressure sodium (HPS) lamps. Scientia Horticulturae 147: 136-143.

JOHANSEN NS; ERIKSEN AS; MORTENSEN L. 2011. Light quality influences trap catches of Frankliniella occidentalis (Pergande) and Trialeurodes vaporariorum (Westwood). Integrated control in protected crops, temperate 
climate IOBC/WPRS Bulletin 68: 89-92.

JOHKAN M; SHOJI K; GOTO F; HAHIDA S; YOSHIHARA T. 2010. Blue light-emitting diode light irradiation of seedlings improves seedling quality and growth after transplanting in red leaf lettuce. HortScience, 45: 18091814.

JOHKAN M; SHOJI K; GOTO F; HAHIDA S; YOSHIHARA T. 2012. Effect of green light wavelength and intensity on photomorphogenesis and photosynthesis in Lactuca sativa. Environmental and Experimental Botany 75: 128-133.

JUNG ES; LEE S; LIM SH; HA SH; LIU KH; LEE CH. 2013. Metabolite profiling of the shortterm responses of rice leaves (Oryza sativa cv. Ilmi) cultivated under different LED lights and its correlations with antioxidant activities. Plant Science 210: 61- 69.

KIM HH; GOINS GD; WHEELER RM; SAGER JC. 2004. Green-light supplementation for enhanced lettuce growth under red- and blue-light-emitting diodes. HortScience 39: 1617-1622.

KÖKSAL N; INNCESU M; TEKE A. 2013. LED aydınlatma sisteminin domates bitkisinin gelişimi üzerine etkileri. (In Turkish) (Effects of led lighting on plant development of tomato). Tarım Bilimleri Araştırma Dergisi 6: 71-75.

LEE SH; TEWARI RK; HAHN EJ; PAEK KY. 2007. Photon flux density and light quality induce changes in growth, stomatal development, photosynthesis and transpiration of Withania Somnifera plantlets. Plant Cell, Tissue and Organ Culture 90: 141-151.
LI H; TANG C; XU Z; LIU X; HAN X. 2012. Effects of different light sources on the growth of non-heading chinese cabbage (Brassica campestris). Journal of Agricultural Science, 4: 262-273.

LI Q; KUBOTA C. 2009. Effects of supplemental light quality on growth and phytochemicals of baby leaf lettuce. Environmental and Experimental Botany 67: 59-64.

MASSA GD; KIM HH; WHEELER RM; MITCHELL CA. 2008. Plant productivity in response to LED lighting. Hortscience, 43: 1951-1956.

MORROW RC. 2008. LED lighting in horticulture. Hortscience 43: 1947-1950.

OLVERA-GONZALEZ E; ALANIZLUMBRERAS D; IVANOV-TSONCHEV R; VILLA-HERNÁNDEZ J; OLVERAOLVERA C; GONZÁLEZ-RAMÍREZ E; ARAIZA-ESQUIVEL M; TORRESARGÜELLES V; CASTAÑO V. 2013. Intelligent lighting system for plant growth and development. Computers and Electronics in Agriculture 92: 48-53.

RUNKLE E; HEINS R. 2004. Florel on summer production of pansy. Gnp 36-38.

SAMUOLIENĖ G; BRAZAITYTÉ A; URBONAVIČIŪTĖ A; ŠABAJEVIENĖ G; DUCHOVSKIS P. 2010. The effect of red and blue light component on the growth and development of frigo strawberries. Zemdirbyste-Agriculture 97:99-104.

SHIN YS; LEE MJ; LEE ES; AHN JH; LIM JH; KIM HJ; PARK HW; UM YG; PARK SD; CHAI JH. 2012. Effect of leds (light emitting diodes) irradiation on growth and mineral absorption of lettuce (Lactuca sativa 'Lollo Rosa'). Journal of Bio-Environment Control 21: 180-185.

SIRTAUTAS R; VIRSILE A; SAMUOLIENE G; BRAZAITYTE A; MILIAUSKIENE J; SAKALAUSKIENE S; DUCHOVSKIS P; 2014. Growing of leaf lettuce (Lactuca sativa) under high-pressure sodium lamps with supplemental blue, cyan and green LEDs. Zemdirbyste-Agriculture 101: 75-78.

SU NN; WU Q; CUI J. 2012. Effects of supplemental lighting with led light quality on growth and photosynthetic characteristics of cucumber seedlings. China Vegetables 1 : 48-54.

WU MC; HOU CY; JIANG CM; WANG YT; WANG CY; CHEN HH; CHANG HM. 2007. A novel approach of LED light radiation improves the antioxidant activity of pea seedlings. Food Chemistry 101: 1753-1758.

YANG ZQ; LI YX; ZHANG JB; ZHANG J; ZHU J; GU LL; ZHANG B. 2013. Effects of the red:far-red light ratio on photosynthetic characteristics of greenhouse cut chrysanthemum. (short communication). Horticultural Science 40: 40-43.

YANG ZC; KUBOTA C; CHIA PL; KACIRA M. 2012. Effect of end-of-day far-red light from a movable LED fixture on squash rootstock hypocotyl elongation. Scientia Horticulturae 136: 81-86.

YEH N; CHUNG JP. 2009. High-brightness LEDs-energy efficient lighting sources and their potential in indoor plant cultivation. Renewable and Sustainable Energy Reviews 13: 2175-2180. 